\title{
MANAGEMENT SYSTEMS ON PRODUCTION AND PHYSICOCHEMICAL TRAITS OF FRUITS OF CONVENTIONALLY AND ORGANICALLY GROWN FIG $^{1}$
}

\author{
ELIAS ARIEL DE MOURA ${ }^{2 *}$, VANDER MENDONÇA ${ }^{3}$, ENOCH DE SOUZA FERREIRA ${ }^{3}$, \\ LUANA MENDES OLIVEIRA ${ }^{3}$, BRUNA ESTER FREITAS MELO ${ }^{3}$
}

\begin{abstract}
Fig (Ficus carica L.) is widely accepted due to its organoleptic and pharmacological properties. Search for innovations to improve the crop management has increased to reduce environmental impacts and improve the organoleptic quality and food safety of the fruits. Thus, this study aimed to evaluate the influence of fertilization methods and plant training systems on the production and physicochemical traits of fig. The experiment was carried out in a randomized complete block design in a $5 \times 4$ factorial scheme, with three blocks and three plants per plot. The factors corresponded to five fertilizers (chemical, cattle manure, sheep manure, poultry litter, and organic compost) and four training systems (two branches, three branches, four branches, and espalier). Results showed that, when using chemical fertilizer and poultry litter, plants showed similar productivity and number of fruits, which had similar firmness, length, and peel color $\left(\mathrm{L}\right.$ and $\left.{ }^{\circ} \mathrm{h}\right)$. The highest production and number of immature fruits were obtained using cattle manure. Soluble solids content and soluble solids content/ titratable acidity ratio were higher in fruits from plants fertilized with cattle manure, sheep manure, and organic compost. On the other hand, plants trained with three and four branches or in espalier produced fruits with the highest soluble solids content and weight. Also, heavier fruits were obtained using chemical fertilization and conducting plants with two, three, and four branches.
\end{abstract}

Keywords: Ficus carica L.. Formative pruning. Organic fertilizer. Organoleptic quality. Organic production.

\section{SISTEMAS DE MANEJO E CARACTERÍSTICAS PRODUTIVAS E FÍSICO-QUÍMICAS DE FRUTOS DE FIGO CULTIVADOS CONVENCIONAL E ORGANICAMENTE}

\begin{abstract}
RESUMO - A figueira (Ficus carica L.) é amplamente aceita devido às suas propriedades organolépticas e farmacológicas. A busca por inovações para aprimorar o manejo da cultura tem aumentado para reduzir os impactos ambientais e melhorar a qualidade organoléptica e a segurança alimentar dos frutos. Assim, este trabalho teve como objetivo avaliar a influência de métodos de fertilização e sistemas de treinamento de plantas na produção e nas características físico-químicas da figueira. O experimento foi conduzido em delineamento de blocos casualizados em esquema fatorial $5 \times 4$, com três blocos e três plantas por parcela. Os fatores corresponderam a cinco fertilizantes (químico, esterco bovino, esterco ovino, cama de aviário e composto orgânico) e quatro sistemas de treinamento (dois ramos, três ramos, quatro ramos e espaldeira). Os resultados mostraram que, com o uso de fertilizante químico e cama de frango, as plantas apresentaram produção, rendimento e número de frutos semelhantes, com firmeza, comprimento e cor de casca semelhantes (L e $\left.{ }^{\circ} \mathrm{h}\right)$. A maior produtividade e número de frutos imaturos foram obtidos com esterco bovino. $\mathrm{O}$ teor de sólidos solúveis e a relação teor de sólidos solúveis / acidez titulável foram maiores nos frutos provenientes de plantas fertilizadas com esterco bovino, esterco ovino e composto orgânico. Por outro lado, plantas treinadas com três e quatro ramos ou em espaldeira produziram frutos com maior teor de sólidos solúveis e peso. Além disso, frutos mais pesados foram obtidos usando fertilização química e plantas condutoras com dois, três e quatro ramos.
\end{abstract}

Palavras-chave: Ficus carica L.. Poda de formação. Fertilizante orgânico. Qualidade organoléptica. Produção orgânica.

\footnotetext{
*Corresponding author

${ }^{1}$ Received for publication in $03 / 19 / 2021$; accepted in $07 / 08 / 2021$.

Paper extracted from the doctoral thesis of the first author.

${ }^{2}$ Graduate Program in Agronomy, Universidade Federal Roraima, Boa Vista, RR, Brazil; eliasariel90@gmail.com - ORCID: 0000-00021459-1310.

${ }^{3}$ Department of plant sciences, Universidade Federal Rural do Semi-Árido, Mossoró, RN, Brazil; vander@ufersa.edu.br - ORCID: 00000001-5682-5341, agro_ferreiraenoch7@outlook.com - ORCID: 0000-0002-3175-154X, lul-ut@hotmail.com - ORCID: 0000-0003-20029313, brunaester2011@live.com - ORCID: 0000-0002-6543-901X
} 


\section{INTRODUCTION}

Fig (Ficus carica L.) has high production potential in the semiarid region because the climatic conditions of this region can favor its growing. Constant and high temperatures in the semiarid region can shorten the crop cycle relative to other regions. In addition, the low air relative humidity decreases the incidence of Cerotelium fici, the main pathogen of fig.

Although fig can easily adapt to climatic conditions, its growth and development vary in different environments (AMMAR et al., 2020). Thus, crop management may improve the plant vegetative growth, productivity, and fruit quality, in addition to reducing the attack of phytopathogens and maximizing the effect of phytosanitary treatments. Moreover, studying management systems in adaptive environments allows obtaining new and viable growing methods.

On the other hand, both pre- and post-harvest management practices in agricultural systems can significantly affect the organoleptic quality of produce (MDITSHWA et al., 2017). Using organic fertilizers in agriculture has shown promise for improving the physical, chemical, and biological properties of the soil and the water dynamics. Also, organic production has increased due to the search for safe, healthy and beneficial foods for human and animal health, due to the disclosure of cases reporting the presence of contaminants in fruits and vegetables from conventional management practices (PAOLETTI, 2015; SUNDRUM, 2010).

Several studies showed that organic cultivation improves fruit quality, both the organoleptic and the nutritional properties. In a metaanalysis with 41 studies, Worthington (2001) observed that the vitamin $\mathrm{C}$ content and other compounds were higher in fruits from organic cultivation. Other studies also demonstrate that organic cultivation improves the organoleptic and nutritional quality of produce (AMODIO et al., 2007; CARDOSO et al., 2011; D'EVOLI et al., 2013; DESHMUKH et al., 2011; LETAIEF et al., 2016).

Although the conventional cultivation system increases the plant potential and reduces costs in agricultural systems (MDITSHWA et al., 2017), it negatively impacts the environment (SUNDRUM, 2010), as well as the nutrition and quality of fruits (PAOLETTI, 2015). Observing the differences in organoleptic quality in organically and conventionally cultivated fruits is extremely important.

Under organic and conventional production, plants respond differently to the types of management, which thus affects the organoleptic quality of fruits. However, several factors may impact the quality of the produce, such as climatic conditions, organic and chemical fertilizers used, and decomposition and mineralization processes.

As studies have been limited to comparing different organic sources, research on the interaction between organic and chemical fertilization and plant training systems is scarce. Thus, this work aimed to evaluate the production and physicochemical traits of fig produced under different training systems and organic and conventional fertilization.

\section{MATERIAL AND METHODS}

\section{Experimental area}

The experiment was carried out at the Rafael Fernandes Experimental Farm ( $5^{\circ} 03^{\prime} 37^{\prime \prime}$ S, 37 ${ }^{\circ} 23^{\prime} 50^{\prime \prime}$ $\mathrm{W}$, flat relief, $78 \mathrm{~m}$ above the sea level), Federal Rural University of the Semiarid Region (UFERSA), Mossoró city, Rio Grande do Norte state, Brazil. The climate of the region is classified as BSw'h according to Köppen's classification, which is hot tropical semiarid with well-defined seasons: dry (prolonged) and humid (short and irregular). The natural vegetation is hyper xerophilous Caatinga. The soil at the experimental farm is classified as a Argissolo Vermelho distrófico típico (Ultisol) (REGO et al., 2016).

During the experimental period, maximum, average, and minimum temperatures, rainfall, and relative humidity were recorded (Figure 1). The climatic data (available at Hobolink) were obtained from the ASA weather station (Meliponário Imperatriz) situated at the experimental farm.

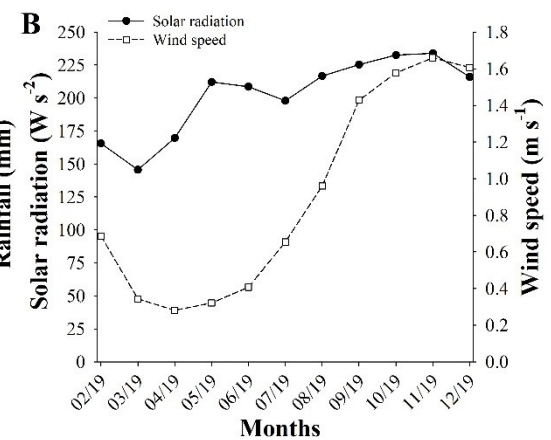

Figure 1. Climatic data during the experiment in 2019. Temperature, relative humidity, and rainfall (A), and wind speed and solar radiation (B) in semiarid conditions. Mossoró, RN. 


\section{Growing conditions and experimental design}

The "Roxo-de-Valinhos" fig trees used in the experiment were 2 years old and were planted in the experimental area with a spacing of $3 \times 2 \mathrm{~m}$. The plants used in the experiment were $40 \mathrm{~cm}$ tall, with different formation structures: two, three and four primary branches per plant, distributed in the shape of a tray, and plants with two primary branches in a vertical espalier (Figure 2).
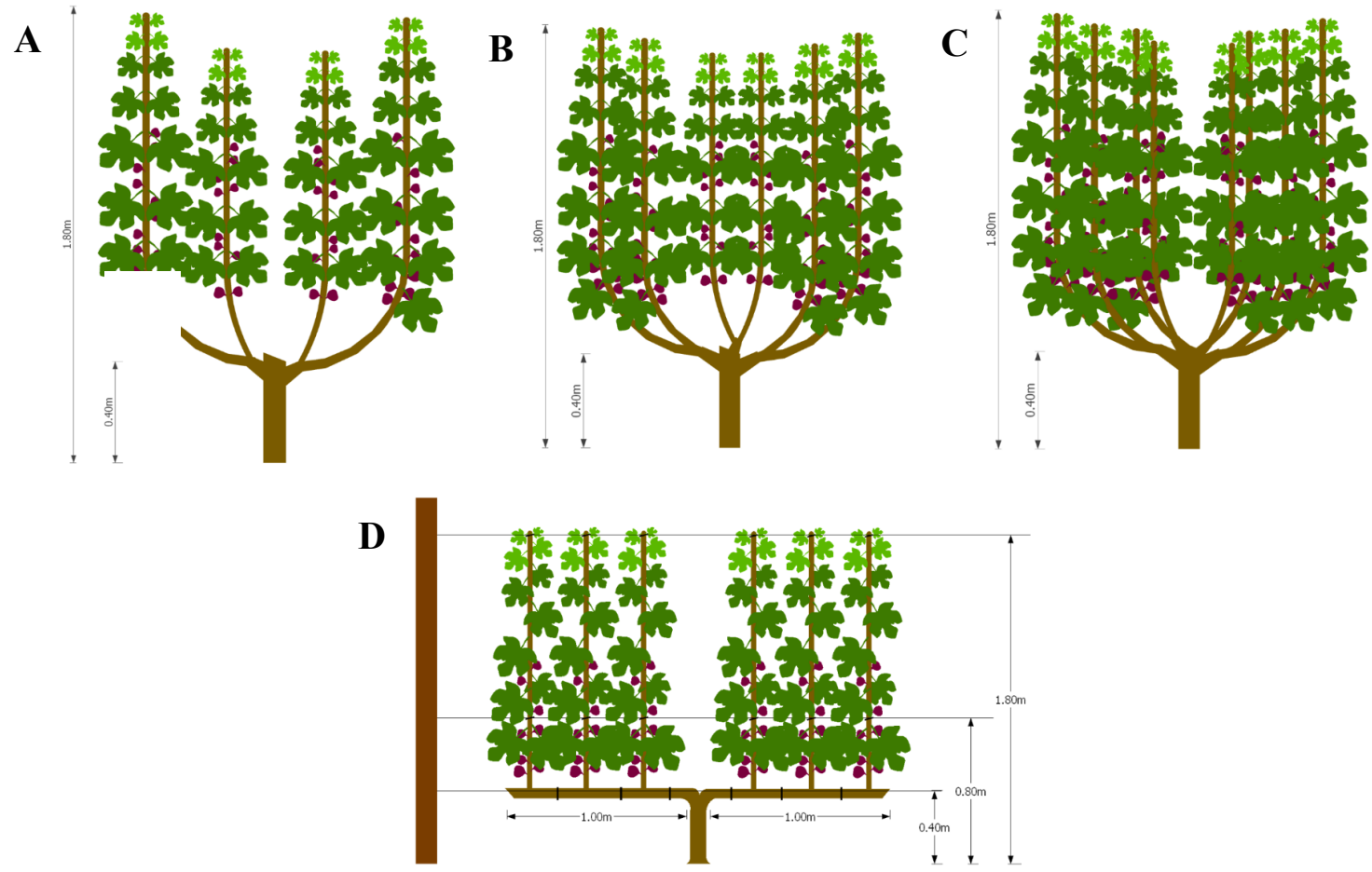

Figure 2. Fig plants conducted with two (A), three (B) and four (C) primary branches and espalier systems (D).

The plants conducted under the espalier system were first pruned at $40 \mathrm{~cm}$ in height. Then, two primary branches with $1.0 \mathrm{~m}$ length were tied horizontally on each side on steel cables. The espalier structure was built using four wooden posts spaced $10 \mathrm{~m}$. The steel cables were stretched at 0.40 , 0.80 , and $1.80 \mathrm{~m}$ height above the soil (Figure 2D).

The first fruit pruning was performed on March 15, 2019. The primary branches from all plants were pruned to $5 \mathrm{~cm}$ in length to allow the sprouting of up to three vegetative buds per branch. Twenty days after pruning, thinning was carried out so that each plant remained with two productive branches per primary branch (two branches - four productive branches (Figure 2A); three branches six productive branches (Figure 2B), and four branches - eight productive branches (Figure $2 \mathrm{C}$ ). In the espalier system, the vertical branches were pruned close to the horizontal branch, thus allowing the growth of new branches. For each side of the horizontal branches, three productive branches were left, totaling 6 productive branches per plant (Figure 2D).

After fruit pruning, the plants were conventionally and organically fertilized. The conventional (mineral) fertilization was $80 \mathrm{~g}$ nitrogen, $60 \mathrm{~g}$ potassium, and $60 \mathrm{~g}$ phosphorus as urea $(46 \% \mathrm{~N})$, potassium chloride $(60 \% \mathrm{~K})$, and monoammonium phosphate $\left(52 \% \quad \mathrm{P}_{2} \mathrm{O}_{5}\right)$, respectively. In turn, the organic sources were organic compost, cattle manure, sheep manure, and poultry litter (chemical characteristics shown in Table 1). Poultry litter was applied fresh while the other organic sources were composted according to Preusch, Takeda and Tworkoski (2004) before use. $\mathrm{N}$ and $\mathrm{K}$ fertilizers were split into three applications: the first at pruning and the remaining every 20 days after pruning. For organic fertilization, each plant received $10 \mathrm{~kg}$ of each organic source according to treatments. The application and incorporation were performed according to Leonel and Reis (2012).

The experimental design was completely randomized blocks in a $4 \times 5$ factorial scheme, with three blocks and three plants per plot. The factors were the four types of formative pruning (plants with two branches, three branches, four branches and under espalier system) and five fertilization managements (mineral fertilizers as $\mathrm{N}, \mathrm{P}, \mathrm{K}$, and organic fertilizers as organic compost, sheep manure, cattle manure, and poultry litter). 
E. A. MOURA et al.

Table 1. Chemical characteristics of soils after the end of the experiment.

\begin{tabular}{ccccccc}
\hline & Samples & $\mathrm{S}$ & $\mathrm{P}$ & $\mathrm{B}$ & $\mathrm{O}$ & $\mathrm{M}$ \\
\hline $\mathrm{N}$ & $\mathrm{g} \mathrm{kg-1}$ & 0.53 & 0.43 & 0.40 & 0.80 & 0.37 \\
$\mathrm{pH}$ & $\left(\mathrm{H}_{2} \mathrm{O}\right)$ & 8.47 & 8.50 & 8.60 & 8.53 & 8.50 \\
$\mathrm{MO}$ & $\mathrm{g} \mathrm{kg-1}$ & 9.93 & 8.18 & 10.89 & 13.16 & 11.06 \\
$\mathrm{P}$ & & 8.13 & 27.13 & 8.33 & 12.70 & 18.30 \\
$\mathrm{~K}^{+}$ & $---\mathrm{mg} \mathrm{dm}^{-3}---$ & 99.13 & 97.77 & 81.77 & 82.87 & 83.63 \\
$\mathrm{Na}^{+}$ & & 56.13 & 62.83 & 31.07 & 37.20 & 51.30 \\
$\mathrm{Ca}^{+2}$ & & 2.23 & 2.17 & 1.90 & 2.07 & 2.10 \\
$\mathrm{Mg}^{+2}$ & & 0.53 & 0.63 & 0.53 & 0.53 & 0.43 \\
$\left(\mathrm{H}^{+} \mathrm{Al}\right)$ & $---\mathrm{cmolc} \mathrm{dm}^{-3}----$ & 0 & 0 & 0 & 0 & 0 \\
$\mathrm{SB}$ & & 3.26 & 3.32 & 2.78 & 2.97 & 2.92 \\
$\mathrm{t}$ & & 3.27 & 3.33 & 2.80 & 2.97 & 2.97 \\
$\mathrm{CTC}$ & $-3,26$ & 3,32 & 2,78 & 2,97 & 2,95 \\
$\mathrm{~V}$ & & 100 & 100 & 100 & 100 & 100 \\
& & 5.67 & 8.33 & 5.33 & 7.33 & 7.33 \\
\hline
\end{tabular}

*soils with sheep manure - S; soils with poultry litter - P; soils with bovine manure - B; soils with organic compost - O; soils with mineral fertilizers - M.

Phosphorus $(\mathrm{P})$ and potassium $\left(\mathrm{K}^{+}\right)$: mehlich $^{-1}$ extractor; calcium $\left(\mathrm{Ca}^{2+}\right)$, magnesium $\left(\mathrm{Mg}^{2+}\right)$, and exchangeable aluminum $\left(\mathrm{Al}^{3+}\right): \mathrm{KCl}^{-1} \mathrm{molL}^{-1}$ extractor; potential acidity $(\mathrm{H}+\mathrm{Al})$ : SMP extractor. $\mathrm{SB}=$ sum of bases; $\mathrm{CECt}=$ effective cation exchange capacity; $\mathrm{V}=$ base saturation.

\section{Production variables}

Productivity was determined as the weight of commercial and immature fruits harvested three times a week and results were expressed in $\mathrm{kg}$ per plant. The productivity of all fruits was determined as the production per planting area, then multiplied by the number of plants, and results were expressed as $\mathrm{tha}^{-1}$.

Moreover, the number of fruits per plant was evaluated by counting the number of commercial, immature, and injured fruits, and total number of fruits. Commercial fruits were those destined for fresh consumption while injured fruits are those without commercial standard, due to physiological, physical, or environmental damage. When all commercial fruits were harvested, immature fruits were also collected to quantify their productivity.

\section{Postharvest quality of fruits}

To determine the average length, diameter, and weight of fruits, ten fruits per plant were evaluated, totaling 30 fruits per plot. All fruits were harvested at the same ripening stage and measured using a digital caliper $( \pm 0.01 \mathrm{~mm})$. The average weight was determined using an analytical scale and results were expressed as $g( \pm 0.01)$.

To evaluate peel color and firmness, ten fruits per plot were used. Peel color was determined using a digital colorimeter (Chroma Meter 400/410, Minolta Corp., Osaka, Japan), and two readings were performed on opposite sides of the fruit. The CIELCH space was used: lightness $\left(\mathrm{L}^{*}\right)$, chroma $\left(\mathrm{C}^{*}\right)$, and hue angle $\left({ }^{\circ} \mathrm{H}\right)$.

Firmness was determined using a digital texture analyzer (TA.XTExpress / TA.XT2icon, Stable Micro Systems) equipped with a $5 \mathrm{~mm}$ diameter tip. Two readings were performed on opposite sides of the fruit, and results were expressed as Newton $(\mathrm{N})$.

The organoleptic properties of fruits were evaluated using 12 fruits per plot, harvested at a $75 \%$ maturation stage. Soluble solids (SS) content was determined directly in the homogenized pulp using a digital refractometer (PR - 100 model, Palette, Atago Co, LTD., Japan), with duplicate readings and results expressed as ${ }^{\circ}$ Brix (AOAC, 2012).

Titratable acidity (TA) was determined by titration, using $1.0 \mathrm{~g}$ pulp diluted with $50 \mathrm{~mL}$ distilled water in a $125 \mathrm{~mL}$ Erlenmeyer. Then, the solution was titrated in duplicate with $0.1 \mathrm{M} \mathrm{NaOH}$ until $8.1 \mathrm{pH}$ and results were expressed as $\mathrm{g}$ citric acid $100 \mathrm{~g}^{-1}$ fresh weight (AOAC, 2012). Hydrogen potential $(\mathrm{pH})$ of pulp was determined using a potentiometer with automatic temperature adjustment (Model mPA-210 Tecnal ${ }^{\circledR}$, Brazil), previously calibrated with 7.0 and $4.0 \mathrm{pH}$ buffer solutions (AOAC, 2012). The maturation index was 
calculated as SS/TA ratio.

Vitamin $\mathrm{C}$ content was determined by titration with Tilman's solution $(0.02 \%$ DFI - 2.6 dichloro-phenol indophenol) as proposed by Strohecker and Henining (1967). $1.0 \mathrm{~g}$ homogenized pulp was used for dilution to $100 \mathrm{ml}$ with $0.5 \%$ oxalic acid in a volumetric flask, and results were expressed as mg ascorbic acid (AsA) $100 \mathrm{~g}^{-1}$ fresh weight.

\section{Statistical analysis}

Data were tested for normality according to the Shapiro-Wilk test and for homogeneity of variances according to Bartlett test $(p<0.05)$. When normality and homogeneity assumptions were met, data were submitted to two-way analysis of variance by the $F$ test $(p<0.05)$ followed by the Tukey test $(p<0.05)$ to group means. All statistical analyses were performed in $\mathrm{R}$ software ( $\mathrm{R}$ CORE TEAM, 2020).

\section{RESULTS AND DISCUSSION}

\section{Production variables}

The commercial production of fruits was higher with chemical fertilization and with poultry litter $(p>0.05)$. These led to higher means than organic compost and sheep manure $(\mathrm{p}<0.05)$.

The productivity of all commercial fruits under chemical fertilization, and organic fertilization using poultry litter, are equivalent to the average productivity in Brazil (10.18 $\left.\mathrm{t} \mathrm{ha}^{-1}\right)$ (FAO, 2017). Under chemical fertilization, plants produced $10.76 \%$ more, on average, as compared to plants under organic fertilization using poultry litter, and $34.14 \%$ more as compared to plants fertilized with cattle manure. Such results were similar to those found by Conti et al. (2014), who obtained 50\% higher production of strawberries under chemical fertilization as compared to fertilization with cattle manure. In a meta-analysis of 316 studies, Seufert, Ramankutty and Foley (2012) observed that the production under conventional fertilization can exceed by $5 \%$ the production under organic fertilization due to variation in climate and soils in Leguminosae and perennial crops, 13\% under good organic practices, and $34 \%$ when conventional and organic management systems are more comparable. Therefore, under good management conditions, productivity under organic management systems, with poultry litter, can be equivalent to that obtained in a conventional system, as we observed in the present study (Table 2).

Table 2. Productivity of commercial, immature, and injured fruits of fig plants grown under organic and conventional fertilization in semiarid conditions.

\begin{tabular}{ccccc}
\hline \multirow{2}{*}{ Fertilizer } & Commercial & Immature & Injured & Total \\
\cline { 2 - 4 } & & \multicolumn{2}{c}{ Productivity $\left(\mathrm{t} \mathrm{ha}^{-1}\right)$} & \\
\hline Organic compost & $3.18 \pm 2.72 \mathrm{c}$ & $0.48 \pm 0.37 \mathrm{~b}$ & $0.19 \pm 0.23 \mathrm{~b}$ & $3.85 \pm 2.91 \mathrm{c}$ \\
Cattle manure & $5.32 \pm 3.74 \mathrm{bc}$ & $1.13 \pm 0.48 \mathrm{a}$ & $0.40 \pm 0.26 \mathrm{bc}$ & $6.85 \pm 4.18 \mathrm{abc}$ \\
Sheep manure & $4.89 \pm 2.90 \mathrm{c}$ & $0.61 \pm 0.66 \mathrm{~b}$ & $0.41 \pm 0.26 \mathrm{bc}$ & $5.91 \pm 3.01 \mathrm{bc}$ \\
Poultry litter & $8.32 \pm 3.29 \mathrm{ab}$ & $0.35 \pm 0.26 \mathrm{~b}$ & $0.61 \pm 0.44 \mathrm{ab}$ & $9.28 \pm 3.66 \mathrm{ab}$ \\
Chemical fertilizer & $9.63 \pm 2.12 \mathrm{a}$ & $0.66 \pm 0.46 \mathrm{~b}$ & $0.96 \pm 0.40 \mathrm{a}$ & $10.40 \pm 4.17 \mathrm{a}$ \\
\hline CV (\%) & 44.66 & 61.81 & 61.11 & 47.98 \\
\hline
\end{tabular}

Values are mean \pm standard deviation. Means followed by same letter in column are not significantly different by the Tukey test $(\mathrm{p}>0.05)$.

Poultry litter is generally richer in nutrients such as nitrogen, calcium, and phosphorus as compared to other organic sources such as cattle manure and organic compost (ABREU et al., 2010). However, a situation observed in the study (Table 1), since the poultry litter used by us had the highest phosphorus content, which may explain the higher fruit productivity obtained with this material compared to other organic sources used.

Cattle manure and poultry litter are widely used as organic fertilizers in agriculture, due to the high nutrient content they have, which benefits the physical, chemical, and biological attributes of the soil and release to plants (PITTA et al., 2012). However, organic fertilizers may have low efficacy due to improper use and lack of information on the quantity to apply (PITTA et al., 2012; SILVA et al., 2014). Thus, nutrient availability at the right time can vary, so that it is necessary to know the dynamics of decomposition and nutrient release of organic fertilizers to synchronize application with the time when plants demand more nutrients (PITTA 
et al., 2012; SILVA et al., 2014).

The productivity of immature fruits was higher using cattle manure as compared to the other fertilizers $(p<0.05)$. Furthermore, fruit losses occurred during development due to the attack of birds and insects, such as the longhorn beetle Dorcacerus barbatus (Cerambycidae). The highest number of injured fruits, classified as unmarketable fruits, were observed under conventional fertilization and using poultry litter ( $p>0.05$ ) (Table 2 ).

Under the semiarid conditions, poultry litter decomposes faster in the first 30 days as compared to cattle manure, decreasing afterward, due to its lower $\mathrm{C} / \mathrm{N}$ and lignin/ $\mathrm{N}$ ratios (SILVA et al., 2014). Also, in the semiarid region, the first 30 days after pruning are crucial for fig plants because of the fast growth and development of productive branches, leaves, and fruits in this phase (SILVA et al., 2017). Therefore, it may explain the higher fruit productivity under poultry litter fertilization, as compared to the other organic fertilizers used. Furthermore, the slow decomposition of cattle manure may delay plant growth and development, which thus evidenced the higher production of immature fruits at harvest.

Several studies have demonstrated the benefits of organic fertilization to plants (DALASTRA et al., 2009). However, only cattle manure has been used as organic fertilizer, which makes it difficult to analyze the effect of different organic sources on crops. Analyzing the application of cattle manure in figs, Dalastra et al. (2009) reported low productivity, around $6.3 \mathrm{t} \mathrm{ha}^{-1}$, and Caetano and Carvalho (2006) obtained $7.5 \mathrm{t} \mathrm{ha}^{-1}$, on average.

Regarding the average number of fruits per plant, plants fertilized with cattle manure showed the highest number of immature fruits, significantly differing from the other treatments $(p<0.05)$. The number of commercial fruits and total number of fruits were higher under mineral fertilization and using poultry litter ( $>0.05)$ (Table 3$)$.

Table 3. Number of immature and commercial fruits of fig plants grown under different training systems and organic and conventional fertilization in semiarid conditions.

\begin{tabular}{cccc}
\hline \multirow{2}{*}{ Fertilizer } & \multicolumn{3}{c}{ Number of fruits } \\
\cline { 2 - 4 } & Commercial & Immature & Total \\
\hline Organic compost & $49.83 \pm 40.85 \mathrm{c}$ & $27.08 \pm 15.75 \mathrm{~b}$ & $74.54 \pm 38.32 \mathrm{c}$ \\
Cattle manure & $88.75 \pm 57.35 \mathrm{bc}$ & $50.08 \pm 21.67 \mathrm{a}$ & $138.83 \pm 67.11 \mathrm{bc}$ \\
Sheep manure & $84.75 \pm 54.72 \mathrm{bc}$ & $28.12 \pm 26.83 \mathrm{~b}$ & $112.62 \pm 49.85 \mathrm{bc}$ \\
Poultry litter & $145.17 \pm 66.05 \mathrm{ab}$ & $22.75 \pm 13.73 \mathrm{~b}$ & $167.92 \pm 69.38 \mathrm{ab}$ \\
Chemical fertilizer & $184.20 \pm 63.30 \mathrm{a}$ & $27.75 \pm 15.71 \mathrm{~b}$ & $211.83 \pm 71.77 \mathrm{a}$ \\
\hline CV $(\%)$ & 52.69 & 56.61 & 42.68 \\
\hline
\end{tabular}

Values are mean \pm standard deviation. Means followed by same letter in column are not significantly different by the Tukey test $(\mathrm{p}>0.05)$

\section{Physicochemical traits of fruits}

The average length of fruits from plants conducted with two branches, three branches or under espalier system was not affected by the fertilization management $(p>0.05)$. However, plants conducted with four branches showed larger fruits in length when they were fertilized with cattle manure, poultry litter, or chemical fertilizer $(\mathrm{p}>0.05)$ (Table $4)$.

Plants fertilized with sheep manure and chemical fertilizer showed no significant difference in fruit length for the tested training systems $(p>0.05)$ (Table 4). Plants fertilized with organic compost showed the largest fruits in length when conducted with two branches, not differing from plants with three branches and under espalier system, but differing from plants with four branches $(p<0.05)$. In turn, plants fertilized with poultry litter had the highest average fruit length when conducted with four branches, with no significant difference from plants with three branches, but differing from plants with two branches and under espalier system $(\mathrm{p}<0.05)$ (Table 4).

For average fruit diameter (FD), plants conducted with two or three branches and under espalier showed no significant difference (Table 4). Whereas in plants with four branches, the largest fruits in diameter were observed under mineral fertilization, with no significant difference as compared to plants fertilized with cattle and sheep manure, but differing from plants fertilized with poultry litter $(\mathrm{p}<0.05)$.

Regarding fruit length and diameter, the number of productive branches and fruits produced by the plants significantly affect fruit size. Plants with four primary branches have eight productive branches, which, therefore, demand a greater amount of photoassimilates during fruit growth and development than plants with fewer branches.

Smaller fruits in diameter in plants fertilized with poultry litter may be due to the fast decomposition rate of this organic material. During the development, fruits increase faster in diameter 
right after their establishment, thus requiring greater nutrient supply in this phase (SILVA et al., 2017). As compared to plants fertilized with other organic materials, plants with four branches and fertilized with poultry litter produced many fruits, and the fertilizer may not have met the nutritional need for fruit growth.

Table 4. Interaction between training systems and fertilizers for length (FL) and diameter of fruits of fig plants grown in semiarid conditions.

\begin{tabular}{ccccc}
\hline \multirow{2}{*}{ Fertilizer } & Two branches & Three branches & Four branches & Espalier \\
\cline { 2 - 5 } & \multicolumn{4}{c}{ Length $(\mathrm{mm})$} \\
\hline Organic compost & $51.05 \pm 0.89 \mathrm{aA}$ & $50.06 \pm 0.41 \mathrm{aAB}$ & $46.48 \pm 2.27 \mathrm{cB}$ & $50.02 \pm 1.50 \mathrm{aAB}$ \\
Cattle manure & $51.75 \pm 2.80 \mathrm{aAB}$ & $53.03 \pm 0.69 \mathrm{aA}$ & $53.39 \pm 2.27 \mathrm{aA}$ & $48.29 \pm 1.69 \mathrm{aB}$ \\
Sheep manure & $50.07 \pm 0.57 \mathrm{aA}$ & $50.71 \pm 1.80 \mathrm{aA}$ & $47.46 \pm 4.37 \mathrm{bcA}$ & $49.79 \pm 1.46 \mathrm{aA}$ \\
Poultry litter & $49.44 \pm 0.19 \mathrm{aB}$ & $51.43 \pm 0.21 \mathrm{aAB}$ & $53.35 \pm 2.05 \mathrm{aA}$ & $48.78 \pm 0.05 \mathrm{aB}$ \\
Chemical fertilizer & $52.82 \pm 1.25 \mathrm{aA}$ & $52.90 \pm 1.29 \mathrm{aA}$ & $51.28 \pm 1.73 \mathrm{abA}$ & $51.79 \pm 1.31 \mathrm{aA}$ \\
\hline CV (\%) & \multicolumn{4}{c}{3.40} \\
\hline \multicolumn{5}{c}{ Diameter $(\mathrm{mm})$} \\
\hline Organic compost & $50.13 \pm 1.60 \mathrm{aAB}$ & $44.84 \pm 1.80 \mathrm{cC}$ & $51.75 \pm 1.52 \mathrm{aA}$ \\
Cattle manure & $49.41 \pm 1.61 \mathrm{aA}$ & $57.73 \pm 2.12 \mathrm{aBC}$ & $49.27 \pm 1.36 \mathrm{abA}$ & $50.36 \pm 1.48 \mathrm{aA}$ \\
Sheep manure & $47.58 \pm 1.52 \mathrm{aA}$ & $50.30 \pm 1.60 \mathrm{aA}$ & $50.59 \pm 1.04 \mathrm{abA}$ & $48.24 \pm 1.54 \mathrm{aA}$ \\
Poultry litter & $50.40 \pm 1.72 \mathrm{aA}$ & $49.51 \pm 1.53 \mathrm{aA}$ & $50.31 \pm 0.63 \mathrm{aA}$ \\
Chemical fertilizer & $50.36 \pm 1.42 \mathrm{aA}$ & $50.16 \pm 0.43 \mathrm{aA}$ & $58.28 \pm 1.15 \mathrm{bA}$ & $50.45 \pm 0.09 \mathrm{aA}$ \\
\hline CV $\%$ ) & \multicolumn{4}{c}{2.85} \\
\hline
\end{tabular}

Values are mean \pm standard deviation. Means sharing an uppercase letter in row or lowercase in column for each variable are not significantly different according to the Tukey test $(\mathrm{p}>0.05)$.

Plants fertilized with cattle manure, sheep manure, poultry litter and chemical fertilizer showed no significant difference in fruit diameter $(\mathrm{p}>0.05)$. However, when fertilized with organic compost, plants had the largest fruits in diameter under espalier system, not differing from plants with two branches, but significantly differing from plants conducted with four branches $(p<0.05)$ (Table 4).

Chemical fertilizer, poultry litter, and cattle manure may release nutrients available to plants in less time, mainly the first two, which explains the discrepancy relative to organic compost and sheep manure. Such greater nutritional availability has been reported in other studies (CONTI et al., 2014; RECHE et al., 2019). The effect of conventional and organic fertilization on fruit diameter is inconsistent in the literature. For passion fruit, there was no difference in diameter of fruits produced under conventional and organic fertilization systems (OLIVEIRA et al., 2017). On the other hand, apples and jujube fruits produced under conventional fertilization were larger in diameter than fruits under organic fertilization (RECHE et al., 2019).

For fruit firmness, the highest averages were observed in plants conducted with two or three branches, under the espalier system, and chemical fertilization. However, there was no statistical difference in firmness when plants were organically fertilized with poultry litter, sheep manure, or cattle manure ( $\mathrm{p}>0.05)$ (Table 5).

Firmness is one of the main attributes for assessing fruit quality. Firmness loss is directly associated with loss of cell turgor, making it one of the main problems for producers and industries
(MDITSHWA et al., 2017). Studies have shown the effect of fertilization management on fruit firmness. In kiwi, the greatest firmness was observed in fruits produced under conventional fertilization as compared to organic one (AMODIO et al., 2007). In contrast, higher firmness was observed in organic fruits (D'EVOLI et al., 2013). One of the causes of low firmness may be due to low $\mathrm{Ca}^{2+}$ supply to fruits. In addition, high nitrogen and potassium supply to plants can reduce fruit firmness, because these nutrients can neutralize the absorption of $\mathrm{Ca}^{2+}$ (AMODIO et al., 2007).

The highest average fruit weight was observed in plants conducted with two branches and under mineral fertilization, being statistically higher than the values of those under fertilization with cattle manure and poultry litter $(p<0.05)$. Plants with four branches produced the smallest fruits when fertilized with organic compost, being statistically inferior to plants fertilized with chemical fertilizer $(\mathrm{p}<0.05)$.

Higher fruit weight in plants with two branches may be favored by better photoassimilate partitioning. Similarly, plants under organic compost fertilization had a smaller number of fruits, which may have favored photoassimilate partitioning. Under chemical and poultry litter fertilization, fruit weight may be positively affected, with the exception of chemical fertilizer in the espalier system. Poultry litter released nutrient faster than the other organic fertilizers, decreasing gradually. Chemical fertilizers, in turn, provide readily available nutrients for plant uptake (CONTI et al., 2014; RECHE et al., 2019). 
E. A. MOURA et al.

Table 5. Interaction between training systems and fertilizers for firmness, hue angle, and weight of fruits of fig plants grown in semiarid conditions.

\begin{tabular}{|c|c|c|c|c|}
\hline \multirow{2}{*}{ Fertilizer } & Two branches & Three branches & Four branches & Espalier \\
\hline & \multicolumn{4}{|c|}{ Firmness $(\mathrm{N})$} \\
\hline Organic compost & $4.25 \pm 0.27 \mathrm{bA}$ & $2.57 \pm 0.93 \mathrm{bA}$ & $2.24 \pm 0.64 \mathrm{aA}$ & $2.30 \pm 0.96 \mathrm{bA}$ \\
\hline Cattle manure & $2.94 \pm 0.60 \mathrm{bA}$ & $2.61 \pm 1.11 \mathrm{bA}$ & $4.94 \pm 2.37 \mathrm{aA}$ & $4.84 \pm 1.88 \mathrm{abA}$ \\
\hline Sheep manure & $3.54 \pm 0.07 \mathrm{bA}$ & $4.78 \pm 2.83 \mathrm{abA}$ & $3.51 \pm 1.69 \mathrm{aA}$ & $2.43 \pm 0.43 \mathrm{bA}$ \\
\hline Poultry litter & $4.88 \pm 3.20 \mathrm{abA}$ & $5.19 \pm 1.68 \mathrm{abA}$ & $3.88 \pm 3.23 \mathrm{aA}$ & $5.21 \pm 0.31 \mathrm{abA}$ \\
\hline Chemical fertilizer & $7.41 \pm 2.01 \mathrm{aA}$ & $7.75 \pm 0.76 \mathrm{aA}$ & $4.32 \pm 0.24 \mathrm{aB}$ & $5.74 \pm 0.38 \mathrm{aAB}$ \\
\hline \multirow[t]{2}{*}{ CV (\%) } & \multicolumn{4}{|c|}{30.94} \\
\hline & \multicolumn{4}{|c|}{ Hue angle $(\mathrm{H})$} \\
\hline Organic compost & $33.55 \pm 4.52 \mathrm{bB}$ & $36.32 \pm 2.72 \mathrm{bcAB}$ & $44.22 \pm 0.40 \mathrm{aA}$ & $27.37 \pm 5.52 \mathrm{bB}$ \\
\hline Cattle manure & $38.23 \pm 3.05 \mathrm{bA}$ & $36.15 \pm 1.34 \mathrm{bcA}$ & $40.57 \pm 6.70 \mathrm{aA}$ & $34.56 \pm 2.51 \mathrm{abA}$ \\
\hline Sheep manure & $35.88 \pm 9.16 \mathrm{bB}$ & $52.66 \pm 1.40 \mathrm{aA}$ & $38.60 \pm 3.88 \mathrm{aB}$ & $33.98 \pm 3.68 \mathrm{abB}$ \\
\hline Poultry litter & $50.82 \pm 6.87 \mathrm{aA}$ & $33.59 \pm 4.81 \mathrm{cBC}$ & $26.18 \pm 2.36 \mathrm{aC}$ & $36.80 \pm 0.09 \mathrm{abB}$ \\
\hline Chemical fertilizer & $49.11 \pm 3.08 \mathrm{aA}$ & $44.45 \pm 5.42 \mathrm{abA}$ & $45.26 \pm 5.15 \mathrm{aA}$ & $39.89 \pm 1.22 \mathrm{aA}$ \\
\hline \multirow[t]{2}{*}{$\mathrm{CV}(\%)$} & \multicolumn{4}{|c|}{10.74} \\
\hline & \multicolumn{4}{|c|}{ Fruit weight (g) } \\
\hline Organic compost & $55.55 \pm 4.99 \mathrm{abAB}$ & $58.68 \pm 0.56 \mathrm{aA}$ & $46.19 \pm 5.81 \mathrm{bB}$ & $57.80 \pm 4.82 \mathrm{aA}$ \\
\hline Cattle manure & $52.72 \pm 2.82 \mathrm{bA}$ & $56.60 \pm 3.86 \mathrm{aA}$ & $53.99 \pm 5.44 \mathrm{abA}$ & $57.76 \pm 5.90 \mathrm{aA}$ \\
\hline Sheep manure & $50.17 \pm 2.96 \mathrm{bB}$ & $57.23 \pm 3.35 \mathrm{aA}$ & $56.07 \pm 2.21 \mathrm{abA}$ & $55.46 \pm 2.99 \mathrm{aA}$ \\
\hline Poultry litter & $55.13 \pm 1.92 \mathrm{abA}$ & $55.57 \pm 2.08 \mathrm{aA}$ & $54.99 \pm 2.83 \mathrm{abA}$ & $54.45 \pm 2.94 \mathrm{aA}$ \\
\hline Chemical fertilizer & $60.47 \pm 2.60 \mathrm{aA}$ & $59.70 \pm 1.39 \mathrm{aAB}$ & $59.86 \pm 2.54 \mathrm{aAB}$ & $53.55 \pm 1.27 \mathrm{aB}$ \\
\hline $\mathrm{CV}(\%)$ & \multicolumn{4}{|c|}{5.54} \\
\hline
\end{tabular}

Values are mean \pm standard deviation. Means sharing an uppercase letter in row or lowercase in column for each variable are not significantly different according to the Tukey test $(\mathrm{p}>0.05)$.

Higher fruit weight in plants with four branches may be favored by the greater capacity of organic fertilizers to support plant growth and development. The plants with four branches and organically fertilized were the least developed in the field. Such behavior may be related to the lower production and number of fruits. A good development favors a high photosynthetic rate in plants, which thus provide higher photosynthate content for the full development of the fruits.

Fruit weight was similar in plants with three branches or under espalier in all tested fertilization methods (Table 5). Likewise, plants fertilized with cattle manure and poultry litter showed fruits with similar weights in all training systems $(p>0.05)$. On the other hand, using organic compost, plants with three branches produced fruits with higher weight, statistically higher than plants with four branches $(\mathrm{p}<0.05)$ (Table 5).

Using sheep manure, plants with three or four branches, or under the espalier system, produced fruits with the highest weights, higher than those of plants with two branches $(\mathrm{p}<0.05)$. Differently, using chemical fertilization, plants with two branches produced fruits with higher weight, significantly higher than the values of those in espalier systems $(\mathrm{p}<0.05)$ (Table 5).

Plants with two, three, and four branches produced heavier fruits when they were chemically fertilized, which can be explained by the greater availability of nutrients for plants (CONTI et al., 2014; RECHE et al., 2019). However, this was not observed for plants under the espalier system. The low productivity in plants under the espalier system may be due to their position in the sun, which may influence their photosynthetic rate (ALCOBENDAS et al., 2012).

The training system and fertilization method did not affect titratable acidity and chroma (C) $(\mathrm{p}>0.05)$, while soluble solids ( ${ }^{\circ}$ Brix) and lightness $\left(\mathrm{L}^{*}\right)$ were affected only by fertilization $(\mathrm{p}<0.05)$. The highest SS contents were obtained using organic 
compost and cattle manure $(\mathrm{p}>0.05)$. However, the SS found using cattle manure did not differ statistically when using the other fertilizers, organic and chemical $(p>0.05)$ (Table 6$)$. $L^{*}$ values were higher under chemical fertilization, being significantly higher than that obtained with cattle manure $(\mathrm{p}<0.05)$ (Table 6).

Table 6. Soluble solids ( ${ }^{\circ}$ Brix) and lightness (L) of fig plants grown in different training systems and under organic and conventional fertilization in semiarid conditions.

\begin{tabular}{ccc}
\hline Fertilizer & \multicolumn{2}{c}{ Chemical traits } \\
\cline { 2 - 3 } & Soluble Solids & Lightness (L) \\
\hline Organic compost & $15.00 \pm 2.66 \mathrm{a}$ & $45.22 \pm 4.09 \mathrm{ab}$ \\
Cattle manure & $13.20 \pm 2.01 \mathrm{ab}$ & $42.37 \pm 5.75 \mathrm{~b}$ \\
Sheep manure & $12.01 \pm 1.70 \mathrm{~b}$ & $46.68 \pm 4.52 \mathrm{ab}$ \\
Poultry litter & $11.58 \pm 2.22 \mathrm{~b}$ & $48.07 \pm 6.04 \mathrm{ab}$ \\
Chemical fertilizer & $11.54 \pm 1.27 \mathrm{~b}$ & $50.09 \pm 2.48 \mathrm{a}$ \\
\hline CV (\%) & 12.99 & 10.56 \\
\hline
\end{tabular}

Values are mean \pm standard deviation. Means followed by same letter in column are not significantly different by the Tukey test $(\mathrm{p}>0.05)$

Differences in plant responses to organic fertilization can be explained by the chemical composition of these materials. Organic compost and cattle manure showed the lowest $\mathrm{Ca}^{2+}$ and $\mathrm{Mg}^{2+}$ contents as compared to the other materials. It may have favored the uptake of $\mathrm{K}^{+}$, which competes for the same absorption site in the plant.

Lightness $(\mathrm{L})$ and hue angle $(\mathrm{H})$ of fruits were lower under organic compost fertilization, which indicates that fruits were more reddish, thus riper, than under the other fertilization managements. Similarly, more reddish strawberries were harvested from plants under organic fertilization as compared to plants under chemical fertilization (VINHA et al.,
2014). Nonetheless, several factors, such as the management practices, maturation stage (most important for fruit color), sunlight incidence, and nutrient supply, can affect the physicochemical traits of fruits and must be taken into account (BRUNETTO et al., 2015; MDITSHWA et al., 2017).

The highest SS/TA was obtained in fruits from plants with three branches fertilized with cattle manure, which was statistically higher than the values obtained with sheep manure, poultry litter and chemical fertilizer $(p<0.05)$. In plants with four branches, the highest SS/TA was obtained using poultry litter $(\mathrm{p}<0.05)$ (Table 7).

Table 7. Interaction between training systems and fertilizers for soluble solids content/titratable acidity ratio (SS/TA) of fruits of fig plants grown in semiarid conditions.

\begin{tabular}{ccccc}
\hline \multirow{2}{*}{ Fertilizer } & \multicolumn{1}{c}{$\begin{array}{c}\text { Two } \\
\text { branches }\end{array}$} & $\begin{array}{c}\text { Three } \\
\text { branches }\end{array}$ & $\begin{array}{c}\text { Four } \\
\text { branches }\end{array}$ & Espalier \\
\cline { 2 - 5 } & \multicolumn{4}{c}{ SS/TA } \\
\hline Organic compost \\
$\begin{array}{c}\text { Cattle } \\
\text { manure }\end{array}$ & $77.64 \pm 15.79 \mathrm{aA}$ & $105.38 \pm 5.46 \mathrm{abA}$ & $99.90 \pm 2.81 \mathrm{aA}$ & $93.13 \pm 10.71 \mathrm{aA}$ \\
$\begin{array}{c}\text { Sheep } \\
\text { manure }\end{array}$ & $81.23 \pm 16.51 \mathrm{aA}$ & $110.91 \pm 25.81 \mathrm{aA}$ & $94.90 \pm 28.42 \mathrm{aA}$ & $83.12 \pm 19.71 \mathrm{aA}$ \\
$\begin{array}{c}\text { Poultry } \\
\text { litter }\end{array}$ & $72.13 \pm 7.03 \mathrm{aB}$ & $71.07 \pm 11.91 \mathrm{bcB}$ & $110.96 \pm 11.31 \mathrm{aA}$ & $65.22 \pm 2.66 \mathrm{aB}$ \\
Chemical fertilizer & $70.08 \pm 18.12 \mathrm{aA}$ & $60.63 \pm 9.35 \mathrm{cA}$ & $88.56 \pm 8.86 \mathrm{aA}$ & $75.91 \pm 6.08 \mathrm{aA}$ \\
\hline CV $(\%)$ & \multicolumn{3}{c}{17.62} \\
\hline
\end{tabular}

Values are mean \pm standard deviation. Means sharing an uppercase letter in row or lowercase in column for each variable are not significantly different according to the Tukey test $(\mathrm{p}>0.05)$.

The organoleptic quality of fruits depends on sugars and organic acids content. Our results showed that the fruits with the best organoleptic qualities were those whose fertilization management and training system promoted higher SS and lower TA.

The fertilization method did not affect the vitamin $\mathrm{C}$ content in fruits in plants with two branches or under the espalier system $(p>0.05)$. 
However, plants with three branches showed the highest vitamin $\mathrm{C}$ content under organic fertilization using sheep manure or poultry litter and under chemical fertilization $(\mathrm{p}>0.05)$. Fruits showed the lowest vitamin $\mathrm{C}$ content when using organic compost, not significantly different when using cattle manure $(\mathrm{p}>0.05)$. Plants with four branches showed the highest vitamin $\mathrm{C}$ content when using sheep manure, which was significantly higher than the value obtained with cattle manure $(\mathrm{p}<0.05)$ (Table 8).

Table 8. Interaction between training systems and fertilizers for vitamin $\mathrm{C}$ content and pulp pH of fruits of fig plants grown in semiarid conditions.

\begin{tabular}{ccccc}
\hline \multirow{2}{*}{ Fertilizer source } & $\begin{array}{c}\text { Two } \\
\text { branches }\end{array}$ & $\begin{array}{c}\text { Three } \\
\text { branches }\end{array}$ & $\begin{array}{c}\text { Four } \\
\text { branches }\end{array}$ & Espalier \\
\cline { 2 - 5 } & \multicolumn{4}{c}{ Vitamin $\mathrm{C}\left(\mathrm{mg}\right.$ ascorbic acid $100 \mathrm{~g}^{-1}$ fresh weight $)$} \\
\hline Organic compost & $70.24 \pm 4.45 \mathrm{aA}$ & $56.93 \pm 4.08 \mathrm{bB}$ & $77.97 \pm 5.38 \mathrm{abA}$ & $76.74 \pm 6.73 \mathrm{aA}$ \\
Cattle manure & $67.88 \pm 5.07 \mathrm{aA}$ & $69.53 \pm 6.20 \mathrm{abA}$ & $67.17 \pm 6.06 \mathrm{bA}$ & $70.21 \pm 7.03 \mathrm{aA}$ \\
Sheep manure & $78.02 \pm 3.50 \mathrm{aAB}$ & $79.67 \pm 8.32 \mathrm{aAB}$ & $83.58 \pm 5.35 \mathrm{aA}$ & $67.49 \pm 2.17 \mathrm{aB}$ \\
Poultry litter & $64.88 \pm 6.49 \mathrm{aA}$ & $71.53 \pm 0.72 \mathrm{aA}$ & $74.70 \pm 6.01 \mathrm{abA}$ & $71.72 \pm 6.0 \mathrm{aA}$ \\
Chemical fertilizer & $72.02 \pm 4.86 \mathrm{aA}$ & $75.33 \pm 7.75 \mathrm{aA}$ & $70.96 \pm 6.63 \mathrm{abA}$ & $77.07 \pm 7.43 \mathrm{aA}$ \\
\hline CV $(\%)$ & \multicolumn{5}{c}{8.40} \\
\hline \multicolumn{5}{c}{ Hydrogen potential $(\mathrm{pH})$} \\
\hline Organic compost & $5.34 \pm 0.17 \mathrm{aBC}$ & $5.92 \pm 0.26 \mathrm{aA}$ & $5.02 \pm 0.09 \mathrm{bC}$ & $5.44 \pm 0.24 \mathrm{abB}$ \\
Cattle manure & $5.33 \pm 0.33 \mathrm{aA}$ & $5.52 \pm 0.19 \mathrm{abA}$ & $5.49 \pm 0.06 \mathrm{aA}$ & $5.61 \pm 0.27 \mathrm{aA}$ \\
Sheep manure & $5.57 \pm 0.25 \mathrm{aA}$ & $5.28 \pm 0.21 \mathrm{bAB}$ & $5.56 \pm 0.09 \mathrm{aA}$ & $5.21 \pm 0.02 \mathrm{abB}$ \\
Poultry litter & $5.26 \pm 0.13 \mathrm{aA}$ & $5.39 \pm 0.15 \mathrm{bA}$ & $5.39 \pm 0.11 \mathrm{abA}$ & $5.12 \pm 0.21 \mathrm{bA}$ \\
Chemical fertilizer & $5.30 \pm 0.10 \mathrm{aB}$ & $5.35 \pm 0.12 \mathrm{bAB}$ & $5.71 \pm 0.12 \mathrm{aA}$ & $5.40 \pm 0.02 \mathrm{abAB}$ \\
\hline CV $(\%)$ & & 5.30 & \\
\hline
\end{tabular}

Values are mean \pm standard deviation. Means sharing an uppercase letter in row or lowercase in column for each variable are not significantly different according to the Tukey test $(\mathrm{p}>0.05)$.

Fertilization using cattle manure, poultry litter, or chemical fertilizer did not affect vitamin C in all training systems $(p>0.05)$. However, using organic compost, vitamin $\mathrm{C}$ was higher in plants with two or four branches, or under espalier, as compared to plants with three branches $(\mathrm{p}<0.05)$. Using sheep manure, the highest content was obtained in plants with four branches, significantly superior to the value obtained in the espalier system $(\mathrm{p}<0.05)$.

The fertilizer applied and the training system used strongly influenced the vitamin $\mathrm{C}$ content of fruits, as also stated by Deshmukh et al. (2011) and Vinha et al. (2014). According to the authors, biotic and abiotic factors, in organic and conventional cultivation systems, can influence the content of bioactive compounds in fruits and vegetables. In a meta-analysis with 41 studies, Worthington (2001) observed that vitamin $\mathrm{C}$ and other phytochemicals were higher in plants under organic cultivation.

The antioxidant capacity of produce is associated with their capacity to neutralize reactive oxygen species (ROS), and other free radicals produced by oxidative stress (OLIVEIRA et al., 2017). Vitamin $C$ is one of the main protective compounds against oxidative damage, along with other vitamins and polyphenols. Studies have shown that crops under organic management produce higher levels of vitamin $\mathrm{C}$ than crops under conventional system (CARDOSO et al., 2011; LETAIEF et al., 2016). For instance, organic tomatoes showed 55\% higher vitamin $\mathrm{C}$ content as compared to those conventionally produced, which was attributed to stress during organic cultivation.

Few studies report a higher vitamin $\mathrm{C}$ content in conventionally grown crops. Cardoso et al. (2011) observed higher levels of vitamin $\mathrm{C}$ in conventionally produced strawberries, but did not find in persimmon (Diospyros kaki). The increase in vitamin $\mathrm{C}$ in conventionally produced fruits is associated with the application of low $\mathrm{N}$ and high $\mathrm{K}$ concentrations (MDITSHWA et al., 2017). In the present study, the concentrations of $\mathrm{N}$ and $\mathrm{K}$ fertilizers were applied as recommended for the crop.

In plants with two branches, fruit pulp $\mathrm{pH}$ was affected by the fertilization method $(p<0.05)$. The highest $\mathrm{pH}$ was found in fruits from plants with three branches and fertilized with organic compost $(\mathrm{p}<0,05)$. With four branches, the highest $\mathrm{pH}$ was obtained when using chemical fertilizer, sheep manure, and cattle manure, being significantly 
different only from organic compost $(\mathrm{p}<0.05)$. Under the espalier system, the highest $\mathrm{pH}$ was found when using cattle manure, being significantly different only from poultry litter $(\mathrm{p}<0.05)$ (Table 8$)$.

The training system affected $\mathrm{pH}$ when plants were fertilized with cattle manure or poultry litter $(\mathrm{p}>0.05)$. In plants with three branches, $\mathrm{pH}$ was higher when using organic compost $(\mathrm{p}<0.05)$. Using sheep manure, $\mathrm{pH}$ was higher in fruits from plants with two, three, and four branches $(p<0.05)$. Using chemical fertilizer, the highest $\mathrm{pH}$ was obtained in plants with four branches $(\mathrm{p}<0.05)$.

As $\mathrm{pH}$ can affect fruit taste, shelf life is a reliability parameter for the fruit organoleptic quality. $\mathrm{pH}$ increases in organically produced fruits due to the increase in the concentration of titratable acids, which are produced by the oxidation of organic acid skeletons during fruit ripening (SANTOS et al., 2013). It was observed in organic tomatoes (VINHA et al., 2014) and Citrus sinensis (LETAIEF et al., 2016).

\section{CONCLUSIONS}

Fig plants fertilized with poultry litter show productivity, number of fruits and fruit firmness similar to those of plants fertilized with chemical fertilizer; therefore, it can be an alternative in the organic management of the fig tree.

Fig plants trained with three branches, four branches, or under the espalier system produce fruits with better organoleptic qualities.

\section{ACKNOWLEDGMENTS}

The authors thank the Coordenação de Aperfeiçoamento de Pessoal de Nível Superior (CAPES) Brazil, for the financial support.

\section{REFERENCES}

ABREU, I. M. O. et al. Qualidade microbiológica e produtividade de alface sob adubação química e orgânica. Ciência e Tecnologia de Alimentos, 30: 108-118, 2010.

ALCOBENDAS, R. et al. Combined effects of irrigation, crop load and fruit position on size, color and firmness of fruits in an extra-early cultivar of peach. Scientia Horticulturae, 142: 128-135, 2012.

AMMAR, A. et al. Seasonal variation of fig tree (Ficus carica L.) physiological characteristics reveals its adaptation performance. South African Journal of Botany, 132: 30-37, 2020.
AMODIO, M. L. et al. A comparative study of composition and postharvest performance of organically and conventionally grown kiwifruits. Journal of the Science of Food and Agriculture, 87: 1228-1236, 2007.

AOAC. Official methods of analysis of AOAC International. 19. ed. Gaithersburg, Md. USA: AOAC International, 2012.

BRUNETTO, G. et al. The role of mineral nutrition on yields and fruit quality in grapevine, pear and apple. Revista Brasileira de Fruticultura, 37: 1089 $-1104,2015$.

CAETANO, L. C. S.; CARVAlHO, A. J. C. DE. Efeito da adubação com boro e esterco bovino sobre a produtividade da figueira $\mathrm{e}$ as propriedades químicas do solo. Ciência Rural, 36: 1150-1155, 2006.

CARDOSO, P. C. et al. Vitamin C and carotenoids in organic and conventional fruits grown in Brazil. Food Chemistry, 126: 411-416, 2011.

CONTI, S. et al. Effects of organic vs. conventional farming system on yield and quality of strawberry grown as an annual or biennial crop in southern Italy. Scientia Horticulturae, 180: 63-71, 2014.

D'EVOLI, L. et al. Post-harvest quality, phytochemicals and antioxidant activity in organic and conventional kiwifruit (Actinidia deliciosa, cv. Hayward). Italian Journal of Food Science, 25: 362 $-368,2013$.

DALASTRA, I. M. et al. Épocas de poda na produção de figos verdes "Roxo de Valinhos" em sistema orgânico na região oeste do Paraná. Revista Brasileira de Fruticultura, 31: 447-453, 2009.

DESHMUKH, S. R. et al. Tissue specific expression of Anthraquinones, flavonoids and phenolics in leaf, fruit and root suspension cultures of Indian Mulberry (Morinda citrifola L.). Plant Omics, 4: 6-13, 2011.

FAO - Food and Agriculture Organization of the United Nations. Food and agriculture data. 2017. Disponível em: <http://www.fao.org/faostat/en/ \#data/QC>. Acesso em: 19 jan. 2020.

LEONEL, S.; REIS, L. L. Potassium Fertilization on Fruits Orchards: A Study Case from Brazil. In: Issaka, R. N. (Ed.). Soil Fertility. Londres, UK: IntechOpen, 2012. s/v, cap. 8, p. 53-210.

LETAIEF, H. et al. Composition of Citrus sinensis (L.) Osbeck cv «Maltaise demi-sanguine» juice. A comparison between organic and conventional 
farming. Food Chemistry, 194: 290-295, 2016.

MDITSHWA, A. et al. Postharvest quality and composition of organically and conventionally produced fruits: A review. Scientia Horticulturae, 216: 148-159, 2017.

OLIVEIRA, A. B. et al. Effects of organic vs. conventional farming systems on quality and antioxidant metabolism of passion fruit during maturation. Scientia Horticulturae, 222: 84-89, 2017.

PAOLETTI, F. Chemical Composition of Organic Food Products. In: CHEUNG, P.; MEHTA, B. (Eds.). Handbook of Food Chemistry. Berlin, Heidelberg: Springer, 2015. s/v,cap.18, p.555-584.

PITTA, C. S. R. et al. Year-round poultry litter decomposition and N, P, K and Ca release. Revista Brasileira de Ciência do Solo, 36: 1043-1053, 2012.

PREUSCH, P. L.; TAKEDA, F.; TWORKOSKI, T. J. $\mathrm{N}$ and $\mathrm{P}$ uptake by strawberry plants grown with composted poultry litter. Scientia Horticulturae, 102: 91-103, 2004.

R CORE TEAM. R: A Language and Environment for Statistical Computing. R Foundation for Statistical Computing. 2020. Disponível em: https:/www.r-project.org/. Acesso em: 16 jan. 2020.

RECHE, J. et al. Effects of organic and conventional farming on the physicochemical and functional properties of jujube fruit. LWT, 99: 438-444, 2019.

RÊGO, L. G. D. S. et al. Pedogenesis and soil classification of an experimental farm in mossoró, state of rio grande do norte, Brazil. Revista Caatinga, 29: 1036-1042, 2016.

SANTOS, J. L. V. et al. Determination of the harvest point of different passion fruit cultivars. Revista Brasileira de Engenharia Agricola e Ambiental, 17: 750-755, 2013.

SEUFERT, V.; RAMANKUTTY, N.; FOLEY, J. A. Comparing the yields of organic and conventional agriculture. Nature, 485: 229-232, 2012.

SILVA, V. B. et al. Decomposição e liberação de N, $\mathrm{P}$ e $\mathrm{K}$ de esterco bovino e de cama de frango isolados ou misturados. Revista Brasileira de Ciência do Solo, 38: 1537-1546, 2014.

SILVA, F. S. O. et al. Phenology and yield of the
"Roxo de Valinhos" fig cultivar in western Potiguar. Revista Caatinga, 30: 802-810, 2017.

STROHECKER, R.; HENINING, H. Análisis de vitaminas: métodos comprobrados. 1 . ed. Madrid: Paz Montalvo, 1967. 42 p.

SUNDRUM, A. Assessing impacts of organic production on pork and beef quality. CAB Reviews: Perspectives in Agriculture, Veterinary Science, Nutrition and Natural Resources, 5: 1-13, 2010.

VINHA, A. F. et al. Organic versus conventional tomatoes: Influence on physicochemical parameters, bioactive compounds and sensorial attributes. Food and Chemical Toxicology, 67: 139-144, 2014.

WORTHINGTON, V. Nutritional Quality of Organic Versus Conventional Fruits, Vegetables, and Grains. The Journal of Alternative and Complementary Medicine, 7: 161-173, 2001. 